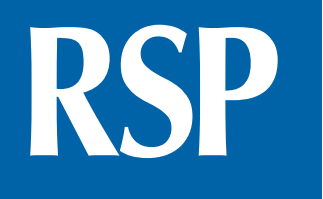

http://www.rsp.fsp.usp.br/

\title{
Gestational weight gain, nutritional status and blood pressure in pregnant women
}

\author{
Chiara Alzineth Silva Campos' ${ }^{1}$, Maira Barreto Malta' (iD, Paulo Augusto Ribeiro Neves' iD, \\ Bárbara Hatzlhoffer Lourenço' (iD, Marcia C Castro" iD, Marly Augusto Cardoso' iD \\ Universidade de São Paulo. Faculdade de Saúde Pública. Departamento de Nutrição, São Paulo, SP, Brasil \\ " Harvard T.H. Chan School of Public Health. Department of Global Health and Population. Boston, MA, EUA
}

\section{ABSTRACT}

OBJECTIVE: To evaluate whether weekly gestational weight gain is associated with anemia, vitamin A insufficiency, and blood pressure levels in the third trimester of pregnancy.

METHODS: A prospective study with 457 pregnant women attending primary care in Cruzeiro do Sul, Acre. The weekly gestational weight gain rate measured between the second and third trimesters was classified as insufficient, adequate, and excessive according to the recommendations of the Institute of Medicine 2009. The outcomes at the beginning of the third gestational trimester were: anemia $(\mathrm{Hb}<110 \mathrm{~g} / \mathrm{L}$ ), vitamin A insufficiency (serum retinol $<1.05 \mu \mathrm{mol} / \mathrm{L}$ ) and blood pressure levels (continuous values, in $\mathrm{mmHg}$ ). Age-adjusted prevalence ratios, schooling, and use of vitamin and mineral supplements were calculated in Poisson regression models with robust variance.

RESULTS: A total of $18.6 \%$ of pregnant women had insufficient weekly weight gain, and 59.1\% had excessive weight gain. The frequencies of anemia, vitamin A insufficiency and hypertension (systolic blood pressure $\geq 140 \mathrm{mmHg}$ or diastolic $\geq 90 \mathrm{mmHg}$ ) were $17.5 \%, 13.4 \%$, and $0.6 \%$, respectively. The prevalence ratios for anemia among pregnant women with insufficient and excessive weight gain were 0.41 (95\%CI 0.18-0.93) and 1.00 (95\%CI 0.63-1.59), respectively, when compared to pregnant women with adequate weight gain. For vitamin A insufficiency, the adjusted prevalence ratio was significantly higher among pregnant women with insufficient weight gain $(2.85,95 \%$ CI 1.55-5.24) and no difference for excessive weight gain $(1.53,95 \% \mathrm{CI}$ 0.84-2.74) when compared to pregnant women with adequate weight gain. Pregnant women with excessive weight gain had higher mean systolic blood pressure (111.10; 95\%CI 109.9-112.2) when compared to pregnant women with insufficient weight gain (107.50; 95\%CI 105.4-109.6) and adequate (106.20; 95\%CI 104.3-108.20).

CONCLUSIONS: Insufficient weekly gestational weight gain was associated with the risk of vitamin A insufficiency. Excessive weight gain, in turn, was associated with higher blood pressure values at the beginning of the third gestational trimester.

DESCRIPTORS: Pregnant Women. Weight Gain. Prenatal Nutrition. Maternal and Child Health. 


\section{INTRODUCTION}

Weight gain is an essential factor in the proper course of pregnancy. It is a complex phenomenon, influenced not only by maternal physiological and metabolic changes but also by placental metabolism ${ }^{1}$. These physiological changes promote the formation and development of amniotic fluid and placenta, increased blood volume, adipose tissue and fetus, and uterine and mammary growth ${ }^{1}$.

Inadequate pre-gestational or gestational nutritional status and inadequate weight gain during pregnancy are associated with poor reproductive outcomes for both the pregnant woman and the baby ${ }^{2}$. Low pre-gestational body weight or insufficient gestational weight gain are associated with intrauterine growth retardation, prematurity, and low birth weight of the baby ${ }^{3}$. On the other hand, pre-gestational obesity or excessive weight gain during pregnancy predisposes women to postpartum hemorrhage, gestational diabetes ${ }^{4}$, preeclampsia and hypertensive pregnancy ${ }^{5}$.

Currently, disorders related to increased occurrence of overweight and obesity coexist with micronutrient and vitamin deficiencies in pregnant women ${ }^{6}$. In this context, anemia stands out as a significant public health problem, currently reaching $29.4 \%$ of women in the world, according to estimates for $2011^{7}$. Anemia in pregnant women affects the health of both the child and the woman, increasing the risk of low birth weight for the baby ${ }^{8}$ and of death, preeclampsia, cardiovascular alterations, and decreased immunological function for the mother 9 . Another essential nutrient for women's health during pregnancy and baby development is vitamin A. During the third gestational trimester, women are more vulnerable to vitamin A deficiency because of physiological increase in blood volume and fetal growth ${ }^{10}$. With respect to high blood pressure levels, arterial hypertension during pregnancy can lead to metabolic and vascular changes associated with increased maternal cardiovascular risk ${ }^{11}$. A study conducted in China ${ }^{5}$ showed an association between a higher pre-gestational body mass index (BMI) and excessive gestational weight gain, with a consequent increased risk for hypertensive pregnancy syndrome ${ }^{5}$.

In Brazil, studies on the relationship between weight gain and nutritional status in pregnancy are scarce, especially in the northern region of the country. According to the latest National Survey of Demographics and Health of Women and Children (PNDS) ${ }^{12}$, about $29 \%$ of women of reproductive age were anemic, and 49\% had serum retinol levels below $1.05 \mu \mathrm{mol} / \mathrm{L}$. Data on the prevalence of anemia and vitamin A status in pregnant women were not collected in the PNDS. Thus, the objective of this study was to evaluate whether weekly gestational weight gain (measured between the second and third gestational trimesters) is associated with the nutritional status of pregnant women at the beginning of the third trimester regarding anemia, vitamin $\mathrm{A}$ and blood pressure levels of pregnant women.

\section{METHODS}

A prospective study involving pregnant women, part of the investigation on maternal and child health and nutrition conditions in Acre (MINA-Brazil). Between February 2015 and February 2016, weekly screening of pregnant women enrolled in the Family Health Strategy (FHS) of Cruzeiro do Sul, Acre, was conducted by the team of researchers in partnership with the city's FHS teams. The inclusion criteria were: gestational age less than 20 weeks based on the date of last menstruation (DLM), having a fixed residence in the municipality, and intention to perform the delivery in the municipality of Cruzeiro do Sul, state of Acre.

The fieldwork team consisted of interviewers (undergraduate nursing and biology students from the Universidade Federal do Acre, Campus Floresta), nursing technicians, nurses, doctors, and researchers (graduate and postdoctoral students) from the Universidade de São Paulo who performed training, supervision and quality control of the data collection. Interviewers conducted home visits to invite participants to the study after clarifying the 
objectives and stages of the research. After consent, sociodemographic information and reproductive and health history were obtained through a structured questionnaire.

Then, using standardized telephone contact, the first clinical evaluations were performed in the second trimester of pregnancy, based on DLM. During the third gestational trimester, a second evaluation was scheduled based on the estimated gestational age assessed in the first evaluation through obstetric ultrasonography. For the two evaluations done by the research team, data were collected on health conditions and life habits of the pregnant woman, anthropometric data and blood sample for biochemical evaluation.

All anthropometric measurements followed the recommendations of the World Health Organization (WHO) ${ }^{2}$ and were carried out by previously trained staff. The body weight measurement was performed in duplicate with a portable scale from Tanita Corporation, Tokyo (Japan), model UM061, with a capacity of $150 \mathrm{~kg}$ and variation of $0.1 \mathrm{~kg}$. Weight was measured with the pregnant woman barefoot, and in light clothes, with upright posture, feet together and arms extended along the body. Height measurement was also performed in duplicate, with bare feet and head free of props and hairstyle, positioned in the center of a portable Alturaexata stadiometer, with the precision of $0.1 \mathrm{~mm}$ and extension of $213 \mathrm{~cm}$.

The mean weekly gestational weight gain was calculated by the difference in the weight measured between the second and third gestational trimesters, divided by the number of gestational weeks in that period. The weekly weight gain intervals recommended by the Institute of Medicine ${ }^{1}$ were used to classify gestational weight gain as insufficient, adequate and excessive according to pre-gestational self-reported BMI (weight in $\mathrm{kg} / \mathrm{height}^{2}$ in meters). For pregnant women aged $\geq 19$ years, pre-gestational BMI was classified according to WHO criteria ${ }^{2}$ : low weight $\left(<18.5 \mathrm{~kg} / \mathrm{m}^{2}\right)$, adequate $\left(18.5-24.9 \mathrm{~kg} / \mathrm{m}^{2}\right)$, overweight $\left(25.0-29.9 \mathrm{~kg} / \mathrm{m}^{2}\right)$ and obesity $\left(\geq 30 \mathrm{~kg} / \mathrm{m}^{2}\right)$. For pregnant women aged less than 19 years, the pre-gestational nutritional status assessment was performed with the WHO Anthro Plus program ${ }^{13}$, which calculates BMI and classifies it into $\mathrm{z}$ score units for age in adolescents compared to the WHO reference ${ }^{14}$. We adopted the following as cut-off points: low weight ( $\mathrm{z}$ score $\leq-2$ ), eutrophic (z score $>-2$ to $\mathrm{z}$ score +1 ), overweight (z score $z+1$ to $\mathrm{z}$ score +2 ) and obesity (z score $\geq+2$ ).

Blood pressure measurements were performed at the beginning of the third trimester in duplicates per trained team, using an OMRON HEM-705CPINT digital device. The following recommendations of the Brazilian Ministry of Health ${ }^{15}$ were deemed: after at least five minutes of rest, sitting with the feet on the floor, with the arm at the same level of the heart and use of an arm cuff of appropriate size. Pregnancy arterial hypertension was defined as the presence of systolic blood pressure $\geq 140 \mathrm{mmHg}$ or diastolic blood pressure $\geq 90 \mathrm{mmHg}$, based on the mean of the two measurements obtained with a 5-minute interval between them ${ }^{16}$.

Blood samples were obtained by fasting for 8 hours at the beginning of the third trimester. A dry tube $(10 \mathrm{~mL})$ for obtaining serum (wrapped with aluminum foil to protect against the light) was kept at room temperature until centrifugation. After centrifugation, the serum was frozen at $-20^{\circ} \mathrm{C}$ and transported within two months to the Human Nutrition Laboratory of the Department of Nutrition, School of Public Health, University of São Paulo, where it was stored at $-70^{\circ} \mathrm{C}$ for further analysis. Blood hemoglobin concentration was analyzed immediately after blood collection with the use of the Hemocue ${ }^{\circledR}$ portable hemoglobinometer (Hb301), using venous blood and cut-off point recommended by $\mathrm{WHO}^{17}$ : hemoglobin during the first and third gestational trimesters less than $110 \mathrm{~g} / \mathrm{L}$ at sea level. Serum retinol concentration was evaluated by reverse-phase high-performance liquid chromatography $(\mathrm{HPLC})^{18}$. According to $\mathrm{WHO}^{19}$ criteria, serum retinol levels $<0.7 \mu \mathrm{mol} / \mathrm{L}$ were classified as vitamin A deficiency and $1.05 \mu \mathrm{mol} / \mathrm{L}$, as vitamin A insufficiency.

For this analysis, the primary exposure variable was the weekly gestational weight gain measured between the second and third gestational trimesters. Outcomes of interest were 
the presence of anemia and vitamin A insufficiency and variations in blood pressure levels at the beginning of the third gestational trimester. Measurements of central tendency (median, mean and standard deviation) and interquartile ranges (IQ25, IQ75) or 95\% confidence intervals $(95 \% \mathrm{CI}$ ) were calculated. The chi-square test was used for comparisons between proportions. Multiple Poisson regression models with robust variance were tested for dichotomous outcomes (anemia and vitamin A insufficiency). P values $<0.20$ and other theoretical assumptions were adopted for the selection of independent variables for multiple analysis. Data analysis was performed using the statistics package Stata 14.0 while adopting a level of significance of $\mathrm{p}<0.05$.

The MINA-Brasil study was approved by the Research Ethics Committee of the Faculdade de Saúde Pública of the Universidade de São Paulo (Opinion 872.613, 13 November, 2014). All participants read and signed the informed consent form.

\section{RESULTS}

In total, 860 pregnant women were identified in the FHS prenatal screening in the urban area of Cruzeiro do Sul. Of them, 161 cases were considered ineligible (abortions, more than 20 gestational weeks or residence in another municipality or rural area), and 111 were follow-up losses (refuse to participate, subjects not found, or nonexistent or incomplete contacting information), remaining 588 participants who answered the socioeconomic and health questionnaire. During the follow-up period, 20 (3\%) pregnant women were excluded (five abortions, five moved to another municipality and 10 moved to rural areas). There were 40 (7\%) losses, including 11 refusals, 17 not found and 12 non-attendances to clinical evaluation, totaling 528 participants (90\% of participants) attending the first evaluation. For the second evaluation, 17 (3\%) were excluded: four had abortions or stillbirths, three moved to another municipality, six moved to rural areas, and three had twin pregnancies. In addition to these, there were $54(10 \%)$ losses with two refusals, 23 pregnant women who were not found and 29 who did not attend the second evaluation. Thus, a total of 458 (78\%) pregnant women performed two clinical evaluations (Figure). There were no statistically significant differences between the participants followed in this study and ones without follow-up concerning the following characteristics: age $(p=0.203)$, skin color $(p=0.127)$, occupation ( $p=0.242)$, pregnant woman head of household ( $p=0.569)$, schooling $(p=0.052)$, primigravidae $(\mathrm{p}=0.987)$ and smoking $(\mathrm{p}=0.132)$. The means for schooling (SD) between pregnant women monitored and without follow-up were 10.5 (2.9) and 9.9 (3.1) years of study, respectively.

In general, pregnant women were younger than 30 years (range: 13 to 40 years), with 19\% of adolescents (out of 89 adolescents, $16 \%$ were between 13 and 16 years old). The majority of the pregnant women self-reported as brown $(\mathrm{n}=348,76 \%)$ and living with a partner $(\mathrm{n}=360,79 \%), 30 \%$ had less than nine years of schooling $(\mathrm{n}=135)$ and $39 \%(\mathrm{n}=179)$ received social benefits. Less than $50 \%$ of the participants were employed, and $14 \%(n=62 \%)$ were heads of household. As for the number of pregnancies, $44 \%$ were primigravidae. The mean gestational age in the second trimester was 19.9 weeks $(\mathrm{SD}=2.8)$, and in the third trimester 27.8 weeks $(\mathrm{SD}=1.6)$.

Table 1 presents the sociodemographic characteristics of the participants according to nutritional status. Age and schooling were positively associated with anemia and not being primigravidae was associated with vitamin A insufficiency. Not having used vitamin supplements during the second or third gestational trimester was associated with anemia and insufficiency of vitamin A.

Table 2 presents the distribution of weekly gestational weight gain stratified according to BMI categories. Among the pregnant women evaluated, 19\% ( $\mathrm{n}=85)$ presented insufficient weight gain and 59\% $(\mathrm{n}=271)$ presented excessive weight gain. Excessive gestational weight gain was predominant in all pre-gestational BMI categories. The descriptive values 


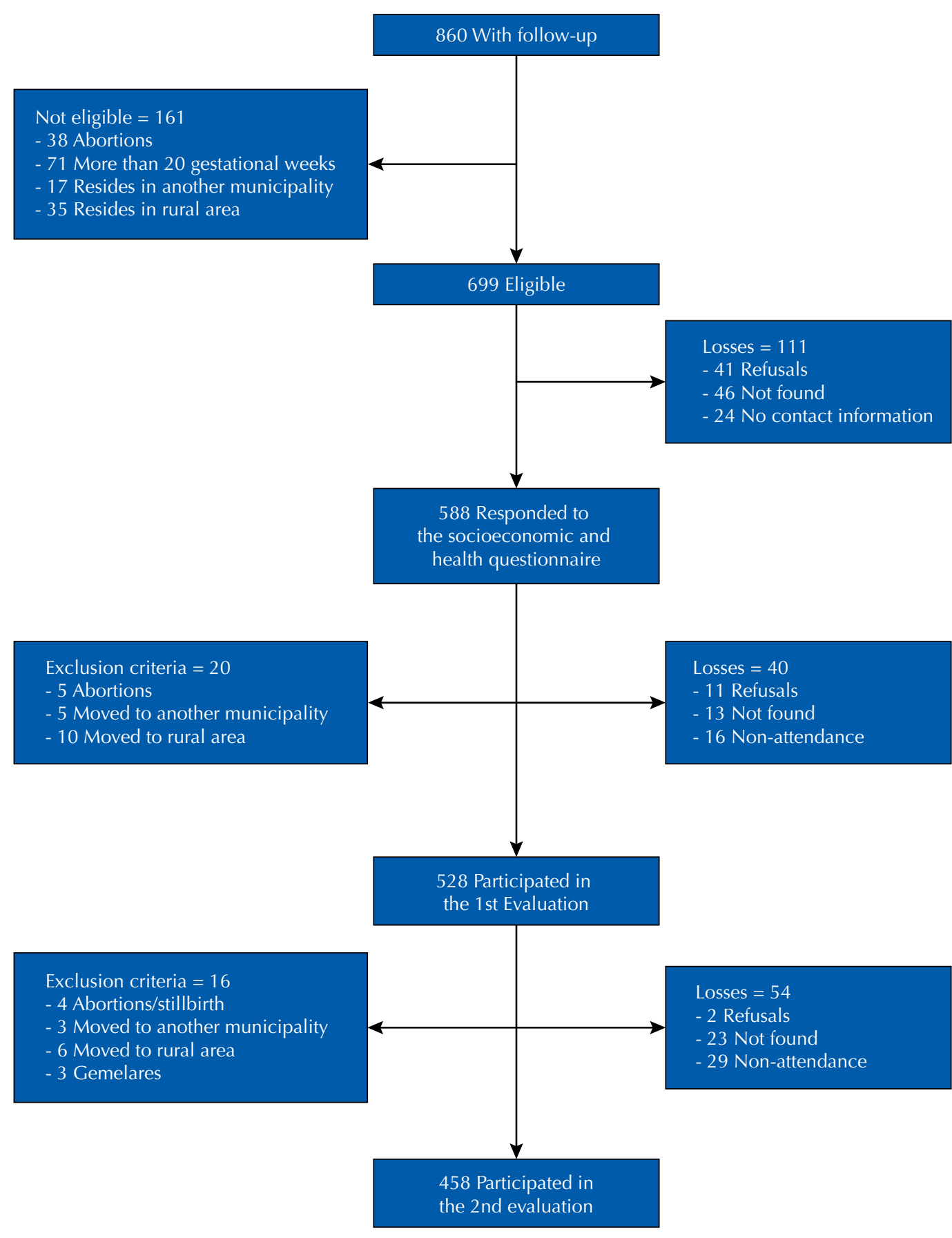

Figure. Flowchart of pregnant women with follow-up, eligible for the study, and follow-up losses. Cruzeiro do Sul, state of Acre, 2015-2016.

of biochemical indicators and pressure levels are presented in Table 3. High frequencies of anemia (18\%), vitamin A deficiency (7\%) and insufficiency (13\%) were observed at the beginning of the third gestational trimester.

Table 4 presents the prevalence ratios for anemia and vitamin A insufficiency according to the recommendation of weekly gestational weight gain. Insufficient weekly weight gain between the second and third gestational trimesters was associated with a lower frequency of anemia (8\%) and higher occurrence of vitamin A insufficiency (33\%) compared to pregnant women with adequate weight gain $(20 \%$ and $12 \%)$, respectively (chi-square test, $\mathrm{p}<0.05)$. The prevalence ratios $(95 \% \mathrm{CI})$ for anemia among pregnant women with insufficient and excessive weight gain were $0.41(0.19-0.96)$ and 1.02 (0.64-1.64), respectively, when compared to pregnant women with adequate weight gain (after being adjusted for age, schooling and use of vitamin and mineral supplements). As for vitamin A insufficiency, prevalence among 
Table 1. Sociodemographic and reproductive characteristics of pregnant women attending prenatal care $(n=458)$ according to occurrence of anemia and vitamin A insufficiency (VAl). Cruzeiro do Sul, state of Acre, 2015-2016.

\begin{tabular}{|c|c|c|c|c|c|}
\hline \multirow[t]{2}{*}{ Variable } & \multirow[t]{2}{*}{ n $(\%)$} & $\begin{array}{c}\text { Anemia } \\
(\mathrm{n}, \%)\end{array}$ & \multirow[t]{2}{*}{$\mathbf{p}$} & $\begin{array}{l}\text { VAI } \\
(n, \%)\end{array}$ & \multirow[t]{2}{*}{$\mathbf{p}$} \\
\hline & & $\mathrm{n}=\mathbf{8 0}$ & & $\mathrm{n}=\mathbf{9 1}$ & \\
\hline \multicolumn{6}{|l|}{ Age (years) } \\
\hline$<19$ & $89(19.4)$ & $26(29.2)$ & \multirow{2}{*}{$0.001 *$} & $23(25.8)$ & \multirow{2}{*}{0.124} \\
\hline$\geq 19$ & $369(80.6)$ & $54(14.7)$ & & $68(18.6)$ & \\
\hline \multicolumn{6}{|l|}{ Schooling } \\
\hline$\leq 9$ years & $135(29.5)$ & $33(24.4)$ & \multirow{2}{*}{$0.011 *$} & $24(18.1)$ & \multirow{2}{*}{0.503} \\
\hline$>9$ years & $323(70.5)$ & $47(14.6)$ & & $67(20.8)$ & \\
\hline \multicolumn{6}{|l|}{ Skin color } \\
\hline White & $70(15.5)$ & $12(17.4)$ & \multirow{2}{*}{0.978} & $12(17.4)$ & \multirow{2}{*}{0.556} \\
\hline Non-white & $388(84.5)$ & $68(17.5)$ & & $79(20.5)$ & \\
\hline \multicolumn{6}{|l|}{ Marital status } \\
\hline With partner & $360(78.6)$ & $62(17.3)$ & \multirow[t]{2}{*}{0.800} & $68(19.1)$ & \multirow[t]{2}{*}{0.332} \\
\hline No partner & $98(21.4)$ & 18 (18.4) & & $23(23.5)$ & \\
\hline \multicolumn{6}{|l|}{ Beneficiary of Bolsa Família } \\
\hline Yes & $179(39.1)$ & $37(20.7)$ & \multirow[t]{2}{*}{$0.153^{*}$} & $42(23.7)$ & \multirow[t]{2}{*}{0.113} \\
\hline No & $279(60.9)$ & $43(15.5)$ & & $49(17.6)$ & \\
\hline \multicolumn{6}{|l|}{ Primigravida } \\
\hline Yes & $202(44.1)$ & $37(18.4)$ & \multirow[t]{2}{*}{0.653} & 48 (23.9) & \multirow[t]{2}{*}{0.066} \\
\hline No & $256(55.9)$ & $43(16.8)$ & & $43(16.9)$ & \\
\hline \multicolumn{6}{|l|}{ Remunerated activity } \\
\hline Yes & $204(44.5)$ & $30(14.8)$ & \multirow{2}{*}{0.170} & $39(19.2)$ & \multirow{2}{*}{0.706} \\
\hline No & $254(55.5)$ & $50(19.7)$ & & $52(20.6)$ & \\
\hline \multicolumn{6}{|l|}{ Pregnant head of household } \\
\hline Yes & $62(13.5)$ & $12(19.7)$ & \multirow{2}{*}{0.632} & $15(24.2)$ & \multirow{2}{*}{0.374} \\
\hline No & $396(86.5)$ & $68(17.2)$ & & $76(19.3)$ & \\
\hline \multicolumn{6}{|c|}{$\begin{array}{l}\text { Supplement during } 2^{\text {nd }} \text { or } 3^{\text {rd }} \text { trimesters of } \\
\text { gestation }\end{array}$} \\
\hline No & $227(49.8)$ & $25(20.3)$ & \multirow{3}{*}{$0.040^{*}$} & 35 (28.9) & \multirow{3}{*}{$0.010^{*}$} \\
\hline Yes, folic acid or iron, or both & $148(32.3)$ & $40(20.6)$ & & $29(14.9)$ & \\
\hline Yes, multivitamin with vitamin A & $82(17.9)$ & $15(10.7)$ & & $27(19.4)$ & \\
\hline
\end{tabular}

Table 2. Classification of weekly gestational weight gain recommended by the Institute of Medicine 2009* according to the categories of pre-gestational BMI. Cruzeiro do Sul, state of Acre, 2015-2016. $(n=458)$

\begin{tabular}{|c|c|c|c|}
\hline \multirow{3}{*}{$\begin{array}{l}\text { Pre-gestational BMI } \\
\text { Categories }\end{array}$} & \multicolumn{3}{|c|}{ Gestational weight gain } \\
\hline & Insuficient & Adequate & Excessive \\
\hline & n (\%) & n (\%) & n (\%) \\
\hline Low weight & $11(33.3)$ & $07(21.2)$ & $15(45.5)$ \\
\hline Normal & $49(17.3)$ & $70(24.7)$ & $164(58.0)$ \\
\hline Overweight & $17(15.7)$ & $18(16.7)$ & $73(67.6)$ \\
\hline Obesity & $08(23.5)$ & $07(20.6)$ & $19(55.9)$ \\
\hline Total & 85 (18.6) & $102(22.3)$ & $271(59.2)$ \\
\hline
\end{tabular}

BMI: body mass index

* Low weight: $<0.44 \mathrm{~kg}$ insufficient weight gain; $\geq 0.44$ to $\leq 0.58 \mathrm{~kg}$ adequate; $>0,58 \mathrm{~kg}$ excessive. Normal: $<0.35 \mathrm{~kg}$ insufficient weight gain; $\geq 0.36$ to $\leq 0.50 \mathrm{~kg}$ adequate; $>0,50 \mathrm{~kg}$ excessive. Overweight: $<0.23 \mathrm{~kg}$ insufficient weight gain; $\geq 0.23$ to $\leq 0.33 \mathrm{~kg}$ adequate; $>0,33 \mathrm{~kg}$ excessive. Obesity: $<0.17 \mathrm{~kg}$ insufficient weight gain; $\geq 0.17$ to $\leq 0.27 \mathrm{~kg}$ adequate; $>0.27 \mathrm{~kg}$ excessive. 
Table 3. Biochemical indicators and blood pressure levels of pregnant women $(n=458)$ in the third trimester. Cruzeiro do Sul, state of Acre, 2015-2016.

\begin{tabular}{lcc}
\hline Variable & $\mathbf{n}$ & Descriptive Values \\
\hline Anemia $(\%, 95 \% \mathrm{Cl})$ & 457 & $17.5(14.1-21.3)$ \\
Hemoglobin, g/L (mean, SD) & 457 & $119.0(98.0)$ \\
Vitamin A, $\mu \mathrm{mol} / \mathrm{L}$ (median, IQ25-75) & 455 & $1.9(1.2-2.7)$ \\
Deficiency of vitamin A, serum retinol $<0.7 \mu \mathrm{mol} / \mathrm{L}(\%, 95 \% \mathrm{Cl})$ & 455 & $6.6(4.5-9.2)$ \\
Vitamin A deficiency, serum retinol < 1.05 $\mu \mathrm{mol} / \mathrm{L}(\%, 95 \% \mathrm{Cl})$ & 455 & $13.4(10.4-16.8)$ \\
Systolic blood pressure, mmHg (mean, SD) & 457 & $109.4(10.0)$ \\
Diastolic blood pressure, $\mathrm{mmHg}$ (mean, SD) & 457 & $65.4(7.5)$ \\
\hline
\end{tabular}

SD: standard deviation; IQ: interquartile range

Table 4. Prevalence, prevalence ratio (PR) and 95\% $\mathrm{Cl}$ for anemia and vitamin A insufficiency according to the classification of weekly gestational weight gain. Cruzeiro do Sul, state of Acre, 2015-2016.

\begin{tabular}{|c|c|c|c|c|c|c|}
\hline \multirow{3}{*}{$\begin{array}{l}\text { Weekly gestational } \\
\text { weight gain }\end{array}$} & \multicolumn{6}{|c|}{ Nutritional indicators in the third trimester of pregnancy } \\
\hline & \multicolumn{2}{|c|}{ Anemia $(n=457)$} & \multicolumn{2}{|c|}{$\begin{array}{l}\text { Vitamin A insufficiency } \\
\qquad(n=455)\end{array}$} & \multirow{2}{*}{$\begin{array}{c}\begin{array}{c}\text { Systolic blood } \\
\text { pressure } \\
(\mathrm{n}=457)\end{array} \\
\text { Mean } \\
(95 \% \mathrm{Cl})\end{array}$} & \multirow{2}{*}{$\begin{array}{c}\begin{array}{c}\text { Diastolic blood } \\
\text { pressure } \\
(\mathrm{n}=457)\end{array} \\
\text { Mean } \\
(95 \% \mathrm{CI})\end{array}$} \\
\hline & n $(\%)$ & $\begin{array}{c}\text { PR } \\
(95 \% \mathrm{CI})^{*}\end{array}$ & n $(\%)$ & $\begin{array}{c}\text { PR } \\
(95 \% \mathrm{CI})^{*}\end{array}$ & & \\
\hline Adequate $(n=102)$ & $\begin{array}{c}20 \\
(19.6)\end{array}$ & 1 & $\begin{array}{c}12 \\
(11.8)\end{array}$ & 1 & $\begin{array}{c}106.3 \\
(104.4-108.3)\end{array}$ & $\begin{array}{c}63.9 \\
(62.4-65.4)\end{array}$ \\
\hline Insufficient $(\mathrm{n}=85)$ & $\begin{array}{c}7 \\
(8.2)\end{array}$ & $\begin{array}{c}0.43 \\
(0.19-0.96)\end{array}$ & $\begin{array}{c}28 \\
(32.9)\end{array}$ & $\begin{array}{c}2.88 \\
(1,57-5,29)\end{array}$ & $\begin{array}{c}107.5 \\
(105.4-109.6)\end{array}$ & $\begin{array}{c}65.1 \\
(63.3-67.0)\end{array}$ \\
\hline Excessive $(n=270)$ & $\begin{array}{c}53 \\
(19.6)\end{array}$ & $\begin{array}{c}1.02 \\
(0.64-1.60)\end{array}$ & $\begin{array}{c}51 \\
(19.0)\end{array}$ & $\begin{array}{c}1.55 \\
(0.86-2.78)\end{array}$ & $\begin{array}{c}111.1 \\
(109.9-112.3)\end{array}$ & $\begin{array}{c}66.1 \\
(65.2-66.9)\end{array}$ \\
\hline
\end{tabular}

* PR estimated by Poisson regression model, adjusted for age, schooling and use of nutritional supplements.

pregnant women with insufficient weight gain (2.88; 95\%CI 1.57-5.29) was higher than among those with adequate weight gain (also after adjusting for age, schooling and use of vitamin and mineral supplements). Regarding systolic blood pressure, pregnant women with excessive weight gain had higher mean systolic blood pressure (111.10; 95\%CI 109.9-112.2) when compared to pregnant women with insufficient weight gain (107.50; 95\%CI 105.4-109.6) and adequate (106.20; 95\%CI 104.3-108.20).

Stratified analyses by age group for the association between gestational weight gain, risk of anemia and vitamin A insufficiency showed similar results. Both with adolescent $(\mathrm{n}=89)$ and adult pregnant women $(\mathrm{n}=368)$, anemia was associated with insufficient gestational weight gain ( $\mathrm{PR}=0.79,95 \% \mathrm{CI} 0.23-2.37$ and $\mathrm{PR}=0.32,95 \% \mathrm{CI} 0.11-0.93$, respectively) and excessive (PR $=0.95,95 \%$ CI $0.44-2.04$ and PR $=1.05,95 \%$ CI 0.60-1.86, respectively). Similarly, with both adolescent $(\mathrm{n}=89)$ and adult $(\mathrm{n}=366)$ pregnant women, vitamin A insufficiency was associated with insufficient gestational weight gain $(\mathrm{PR}=2.98,95 \% \mathrm{CI} 1.10-8,6$ and $\mathrm{RP}=2.93$, 95\% CI 1.38-6.21, respectively) and excessive ( $\mathrm{PR}=0.94$ (95\% CI 0.34-2.61 and $\mathrm{RP}=1.80$; 95\% CI 0.88-3.69, respectively). Only the risk for anemia among adolescent pregnant women with insufficient weight gain lost statistical significance (data not shown in the table).

\section{DISCUSSION}

This is the first longitudinal study in a municipality in the interior of Acre, in the Brazilian Western Amazon, to evaluate the association between gestational weight gain, nutritional status, and pressure levels during the third trimester of gestation. Inadequate weekly gestational weight gain was associated with anemia and insufficient vitamin A (insufficient weight gain) and high blood pressure (excessive weight gain) during the third trimester of pregnancy. 
The high percentage of inadequate weight gain in our study was also described in previous national studies. The proportion of excessive weight gain in this study was similar to that found by Fernandes et al. ${ }^{20}$, in a study conducted in Rio de Janeiro, where $66 \%$ of overweight pregnant women had excessive weight gain at the end of gestation. Carvalhaes et al. ${ }^{21}$, in the countryside of São Paulo state, found $78 \%$ of excessive gestational weight gain among pregestational overweight women. However, in these studies, there was no investigation on the association between weight gain and the nutritional state of pregnant women.

Comparing our results with the previous studies, we found that even though Cruzeiro do Sul was a municipality with lower human development index $(\mathrm{HDI}=0.64)^{22}$ compared to municipalities in the Southeast region, there was a high frequency of excessive gestational weight gain among pregnant women with pre-gestational overweight. One possible explanation may be the change in the food pattern of the Brazilian population, with a reduction in the intake of minimally processed foods and an increase in the consumption of sugar, fat and ultra-processed foods ${ }^{23}$. In this case, it is worth emphasizing the importance of prenatal care in the support and protection of pregnant women against common complications of excessive gestational weight gain for both mother and child, such as macrosomia, hemorrhage, and hypertensive gestational disease, contributing to a better indication for childbirth cesarean section ${ }^{4,24}$.

There is a shortage of studies evaluating gestational weight gain per trimester ${ }^{1}$ and the impacts of inadequate weight gain on maternal health. In a multicenter study conducted in Brazil with 2,244 pregnant women, Drehmer et al. ${ }^{25}$ investigated the association between weekly weight gain during the second and third trimesters, ranked according to recommendations from the 2009 Institute of Medicine, and maternal and fetal outcomes. In that study ${ }^{25}$, in the third trimester, excessive weight gain was associated with preterm birth $(\mathrm{RR}=1.70,95 \% \mathrm{CI} 1.08-2.70)$ and cesarean delivery $(\mathrm{RR}=1.21,95 \% \mathrm{CI} 1.03-1.44)$. Also, women with a gestational weight gain lower than recommended for the second trimester had a lower risk for cesarean delivery $(\mathrm{RR}=0.82,95 \% \mathrm{CI} 0.71-0.96)$ than women with adequate gestational weight gain.

The identification of inadequate weight gain outcomes on maternal nutritional status may be useful for the development of preventive strategies. In this study, the frequency of anemia among women with insufficient weight gain was statistically lower than those with adequate or excessive weight gain. According to a stratified analysis for adolescents and adults, this association remained statistically significant only among adult pregnant women, probably due to the higher number of adult pregnant women. It can be inferred that what occurred, in this case, was hemodilution, a physiological phenomenon in gestation which occurs the increasing in plasma volume higher than the increase in erythrocyte mass, causing a decrease in hemoglobin and hematocrit concentrations, leading to "physiological anemia" 26,27 . Additionally, the pregnant women are more likely to have some regional specificity not identified in this study that contributes to a lower occurrence of anemia at the beginning of the third trimester of gestation, even in the face of a deficit in weight gain.

About the nutritional status of vitamin A, hypovitaminosis A has been considered a public health problem in developing countries. However, there are few studies on the nutritional status of vitamin A in pregnant women in the northern region of Brazil. In our study, when considering all pregnant women, insufficient or excessive gestational weight gain presented a higher chance of vitamin A insufficiency. According to stratified analysis, both adolescent and adult pregnant women with insufficient gestational weight gain presented the risk of vitamin A insufficiency than pregnant women in the same age group with adequate gestational weight gain. This is an important finding that suggests inadequacy in the dietary pattern of these pregnant women, not only concerning to energy intake but also regarding the micronutrient adequacy of the diet. It is likely that the consumption of regional foods naturally rich in beta-carotene (pro-vitamin A), such as pupunha and buriti, among others, is inadequate to our study population, as observed for the Brazilian population in 
the Pesquisa de Orçamentos Familiares ${ }^{28}$, which showed a $69 \%$ inadequacy in vitamin A intake among women of reproductive age in 2011.

In another study, Dos Santos et al. ${ }^{29}$ compared food intake and prevalence of inadequate nutrient intake among 322 pregnant women, 751 infants, and 6,837 non-pregnant and non-lactating women in a country-level representative sample. In that study, inadequate intake of vitamin A was frequent in non-pregnant and pregnant women, increasing during lactation. In a population-based prospective cohort study with 6,959 mothers and their children in the Netherlands, Gaillard et al..$^{30}$ evaluated the risk factors for maternal obesity and excessive gestational weight gain and maternal, fetal and infant outcomes. Maternal obesity was associated with increased risk for gestational hypertension (OR $=6.31,95 \% \mathrm{CI}$ 4.30-9.26), pre-eclampsia ( $\mathrm{OR}=3.61,95 \% \mathrm{CI} 2.04-6.39)$ and gestational diabetes $(\mathrm{OR}=6.28$; 95\% CI 3.01-13.06).

In this study, excessive gestational weight gain was associated with higher mean systolic blood pressure values. The mean systolic (SBP) and diastolic (DBP) blood pressure observed among participants were $109.4 \mathrm{mmHg}$ and $65.4 \mathrm{mmHg}$, respectively, considered within average-range values by the Brazilian Society of Cardiology $y^{16}$, which is probably due to the profile of pregnant women enrolled in low-risk prenatal care in primary health care. The occurrence of hypertension in our study was low (three cases, $0.6 \%$ ). However, pregnant women with excessive gestational weight gain had a higher mean SBP value, which reinforces the need for improvements in maternal care for excessive weight gain during pregnancy, seeking to prevent elevated blood pressure at the end of pregnancy.

Among the limitations of this study, the lack of detailed information on dietary intake during gestation, which was also lacking in previous studies, did not allow to speculate the relationship between insufficient gestational weight gain and bioavailable iron intake for these women. Another significant limitation is related to self-reported pre-gestational weight information, which is susceptible to information bias. However, this limitation was also identified in previous prospective studies because of the difficulty in accurately obtaining this information before gestation. In addition, the location difficulties in our study (due to changes or loss of contact) of the participants contributed to the losses of follow-up between the first $(n=528)$ and the second evaluations $(n=458)$. However, considering the nature of prospective studies in Amazonian municipalities, this follow-up loss of less than $20 \%$ was similar to that observed in previous epidemiological studies ${ }^{11,20,21,23}$.

Lastly, among pregnant women enrolled in the FHS prenatal care in the interior of Acre, insufficient gestational weight gain was associated with a lower occurrence of anemia and a higher risk for vitamin A insufficiency; excessive gestational weight gain, in turn, was associated with higher systolic blood pressure values. The findings of this study contribute to the knowledge about the relationship between gestational weight gain and the nutritional status of pregnant women in primary health care. Nutrition care actions related to the promotion of healthy eating practices should be included in the routine of prenatal care to prevent unfavorable outcomes in this population.

\section{REFERENCES}

1. Institute of Medicine (US); National Research Council. Weight gain during pregnancy: reexamining the guidelines. Washington, DC: National Academies Press; 2009 [cited 2017 Jan 16]. Available from: https528://www.ncbi.nlm.nih.gov/books/NBK32813/

2. World Health Organization. Maternal anthropometry and pregnancy outcomes: a WHO collaborative study. Bull World Health Organ. 1995 [cited 2017 Feb 16];73 Suppl. Available from: http://apps.who.int/iris/bitstream/10665/52910/1/bulletin_1995_Vol73_ supp_\%28part1\%29.pdf

3. Black RE, Victora CG, Walker SP, Bhutta ZA, Christian P, Onis M, et al. Maternal and child undernutrition and overweight in low-income and middle-income countries. Lancet. 2013;382(9890):427-51. https://doi.org/10.1016/S0140-6736(13)60937-X 
4. Poston L, Caleyachetty R, Cnattingius S, Corvalán C, Uauy R, Herring S, et al. Preconceptional and maternal obesity: epidemiology and health consequences. Lancet Diabetes Endocrinol. 2016;4(12):1025-36. https://doi.org/10.1016/S2213-8587(16)30217-0

5. Li N, Liu E, Guo J, Pan L, Li B, Wang P, et.al. Maternal prepregnancy body mass index and gestational weight gain on pregnancy outcomes. PLoS One. 2013;8(12):e82310. https://doi.org/10.1371/journal.pone.0082310

6. Food and Agriculture Organization of the United Nations. Panorama of Food and Nutritional Security in Latin America and the Caribbean 2014: executive summary. Santiago (CL): FAO; 2014 [cited 2017 Feb 10]. Available from: http://www.fao.org/3/a-i4230e.pdf

7. World Health Organization. The global prevalence of anaemia in 2011. Geneva: WHO; 2015 [cited 2016 Nov 10]. Available from: http://www.who.int/nutrition/publications/micronutrients/ global_prevalence_anaemia_2011/en/

8. Black RE, Allen LH, Bhutta ZA, Caulfield LE, Onis M, Ezzati M, et al. Maternal and child undernutrition: global and regional exposures and health consequences. Lancet. 2008;371(9608):243-60. https://doi.org/10.1016/S0140-6736(07)61690-0

9. Ministério da Saúde (BR), Secretaria de Atenção à Saúde, Departamento de Atenção Básica. Atenção ao pré-natal de baixo risco. Brasília, DF; 2012 [cited 2017 Feb 16]. (Série A. Normas e Manuais Técnicos; Cadernos de Atenção Básica, n 32). Available from: http://bvsms.saude.gov. br/bvs/publicacoes/cadernos_atencao_basica_32_prenatal.pdf

10. Organização Mundial da Saúde. Diretriz: suplementação de vitamina A em mulheres no pós-parto. Genebra: OMS; 2013 [cited 2017 Fev 16]. Available from: http://apps.who.int/iris/ bitstream/10665/44623/31/9789248501777_por.pdf

11. Gaio DS, Schmidt MI, Duncan BB, Nucci LB, Matos MC, Branchtein L. Hypertensive disorders in pregnancy: frequency and associated factors in a cohort of Brazilian women. Hypertens Pregnancy. 2001;20(3):269-81. https://doi.org/10.1081/PRG-100107829

12. Ministério da Saúde (BR); Centro Brasileiro de Análise e Planejamento. Pesquisa Nacional de Demografia e Saúde da Criança e da Mulher - PNDS 2006: dimensões do processo reprodutivo e da saúde da criança. Brasília, DF; 2009 [cited 2017 Feb 16]. (Série G. Estatística e Informação em Saúde). Available from: http://bvsms.saude.gov.br/bvs/publicacoes/pnds_ crianca_mulher.pdf

13. WHO Anthro Plus for personal computers: software for assessing growth of the world's children and adolescents. Geneva: WHO; 2009 [cited 2017 Feb 16]. Available from: http://www.who.int/ growthref/tools/en/

14. Onis M, Onyango AW, Borghi E, Siyam A, Nishida C, Siekmann J. Development of a WHO growth reference for school-aged children and adolescents. Bull World Health Organ. 2007;85(9):660-7. https://doi.org/10.2471/BLT.07.043497

15. Ministério da Saúde (BR), Secretaria de Atenção à Saúde, Departamento de Ações Programáticas Estratégicas. Gestação de alto risco: manual técnico. 5. ed. Brasília, DF; 2010 [cited 2017 Feb 16]. (Série A. Normas e Manuais Técnicos). Available from: http://bvsms.saude.gov.br/bvs/ publicacoes/manual_tecnico_gestacao_alto_risco.pdf

16. Malachias MVB, Figueiredo CEP, Sass N, Antonello IC, Torloni MR, Bortolotto MRFL. $7^{\text {a }}$ Diretriz Brasileira de Hipertensão Arterial: Capítulo 9 - Hipertensão arterial na gestação. Arq Bras Cardiol. 2016 [cited 2017 Feb 10];107(3 Suppl 3):49-52. Available from: http://www. scielo.br/scielo.php?script=sci_arttext\&pid=S0066-782X2016004800049\&lng=en \&nrm=iso $\& \mathrm{t} \operatorname{lng}=\mathrm{pt}$

17. World Health Organization. Guideline: daily iron and folic acid supplementation in pregnant women. Geneva: WHO; 2012 [cited 2017 Feb 16]. Available from: http://apps.who.int/iris/ bitstream/10665/77770/1/9789241501996_eng.pdf

18. Gomes LF, Alves AF, Sevanian A, Peres CA, Cendoroglo MS, Mello-Almada C, et al. Role of $\beta_{2}$-glycoprotein I, LDL-, and antioxidant concentrations in hypercholesterolemic elderly subjects. Antioxid Redox Signal. 2004;6(2):237-44. https://doi.org/10.1089/152308604322899305

19. World Health Organization. Indicators for assessing vitamin A deficiency and their application in monitoring and evaluating intervention programmes. Geneva: WHO; 1996 [cited 2017 Feb 10]. (Micronutrient Series). Available from: http://whqlibdoc.who.int/hq/1996/WHO_ NUT_96.10.pdf

20. Fernandes TA; Werneck GL; Hasselmann MH. Prepregnancy weight, weight gain during pregnancy, and exclusive breastfeeding in the first month of life in Rio de Janeiro, Brazil. J Hum Lact. 2012;28(1):55-61. https://doi.org/10.1177/0890334411429113 
21. Carvalhaes MABL, Gomes CB, Malta MB, Papini SJ, Parada CMGL. Sobrepeso pré -gestacional associa-se a ganho ponderal excessivo na gestação. Rev Bras Ginecol Obstet. 2013;35(11):523-9. https://doi.org/10.1590/S0100-72032013001100008

22. Programa das Nações Unidas para o Desenvolvimento; Instituto de Pesquisa Econômica Aplicada; Fundação João Pinheiro. Índice de Desenvolvimento Humano Municipal Brasileiro. Brasília, DF: PNUD Brasil; IPEA; FJP; 2013 [cited 2017 Feb 16]. (Série Atlas do Desenvolvimento Humano no Brasil). Available from: http://www.br.undp.org/content/brazil/pt/home/library/idh/ Atlas/o-idh-brasileiro0.html

23. Monteiro CA, Mondini L, Souza ALM, Popkin BM. Da desnutrição para a obesidade: a transição nutricional no Brasil. In: Monteiro C, organizador. Velhos e novos males da saúde no Brasil: a evolução do país e suas doenças. 2. ed. São Paulo: Hucitec; Nupens USP; 2000. (Saúde em Debate, $n^{\circ}$ 91). p. 247-55.

24. Winkvist A, Brantsaeter AL, Brandhagen M, Haugen M, Meltzer HM, Lissner L. Maternal Prepregant Body Mass Index and gestacional weight gain are associated with initiation and duration of breastfeeding among Norwegian mothers. J Nutr. 2015;145(6):1263-70. https://doi.org/10.3945/jn.114.202507

25. Drehmer M, Duncan BB, Kac G, Schmidt MI. Association of second and third trimester weight gain in pregnancy with maternal and fetal outcomes. PLoS One. 2013;8(1):e54704. https://doi.org/ 10.1371/journal.pone.0054704

26. Centers for Disease Control and Prevention. Recommendations to prevent and control iron deficiency in the United States. MMWR Recomm Rep. 1998;47(RR3):1-29.

27. Souza AI, Filho MB, Ferreira LOC. Alterações hematológicas e gravidez. Rev Bras Hematol Hemoter. 2002;24(1):29-36. https://doi.org/10.1590/S1516-84842002000100006

28. Instituto Brasileiro de Geografia e Estatística. Pesquisa de Orçamentos Familiares 2008 -2009: tabelas de composição nutricional dos alimentos consumidos no Brasil. Rio de Janeiro: IBGE; 2011 [cited 2016 Sep 10]. Available from em: https://biblioteca.ibge.gov.br/visualizacao/livros/ liv50002.pdf

29. Santos Q, Sichieri R, Marchioni DM, Verly Junior E. Brazilian pregnant and lactating women do not change their food intake to meet nutritional goals. BMC Pregnancy Childbirth. 2014;14:186. https://doi.org/10.1186/1471-2393-14-186

30. Gaillard R, Durmuș B, Hofman A, Mackenbach JP, Steegers EA, Jaddoe VW. Risk factors and outcomes of maternal obesity and excessive weight gain during pregnancy. Obesity. 2013;21(5):1046-55. https://doi.org/10.1002/oby.20088

Funding: Conselho Nacional de Desenvolvimento Científico e Tecnológico (CNPq - Process 407255/2013-3 and 133924/2015-7). Fundação Maria Cecília Souto Vidigal, and Fundação de Amparo à Pesquisa do Estado de São Paulo (FAPESP - Process 2016/00270-6). CASC received a scholarship from CNPq through the Post-Graduate Program in Public Health of University of São Paulo.

Authors' Contributions: Conception and planning of the study: CASC, MBM, MAC. Data collection, analysis and interpretation: CASC, PARN, MBM. Elaboration or revision of the manuscript: CASC, MBM, BHL, MCC, MAC. Approval of the final version: CASC, MBM, BHL, MCC, MAC, PARN. Public responsibility for the content of the article: CASC, MBM, MAC.

Conflict of Interest: The authors declare no conflicts of interest. 